\title{
THE EVALUATION OF BIOTHERMAL CONDITIONS FOR VARIOUS FORMS OF CLIMATIC THERAPY BASED ON UTCI ADJUSTED FOR ACTIVITY
}

\author{
Katarzyna Lindner-Cendrowska ${ }^{1}$ (D) Peter Bröde ${ }^{2}$ \\ ${ }^{1}$ Institute of Geography and Spatial Organization \\ Polish Academy of Sciences \\ Twarda 51/55, 00-818 Warsaw: Poland \\ e-mail: klindner@twarda.pan.pl (corresponding author) \\ ${ }^{2}$ Leibniz Research Centre for Working Environment and Human Factors \\ TU Dortmund (IfADo) \\ Dortmund, Germany \\ e-mail: broede@ifado.de
}

\begin{abstract}
The objective of this study was to assess biothermal conditions in the selected Polish health resorts for specific forms of climatic therapy. We calculated Universal Thermal Climate Index (UTCI) for ten-year period (20082017) and then added adjustment terms, taking into account changes in metabolic rates during various physical activities from resting to vigorous exercise. The adjusted UTCI values increased with rising activity, implying that warmer parts of the year were unsuitable for intensive forms of climatotherapy. These results demonstrate that the UTCI adjustment procedure provides well-balanced assessments of bioclimatic conditions for the purpose of climatic treatment considering the level of activity.
\end{abstract}

\section{Key words}

$\mathrm{UTCl} \cdot$ thermal comfort $\cdot$ metabolic heat production $\cdot$ climatic therapy $\bullet$ health resorts

\section{Introduction}

Climatic therapy (also called climatotherapy) is a popular treatment applied worldwide in health and SPA resorts (Kozłowska-Szczęsna et al., 2002; Kazandjieva et al., 2008; Kanayama et al., 2017), which exploits the beneficial properties of local climates in prophylaxis and rehabilitation (Mączyński, 1978).
It functions by exposing the patient to meteorological stimuli (air temperature and humidity, barometric pressure and sunlight) of adequate intensity for a certain period of time, which induces functional, metabolic and morphological changes in the human body (Ponikowska, 1995; Routh et al., 1996). The most popular forms of climatotherapy in Polish health resorts are heliotherapy 
(solar radiation treatment; sunbathing with focus on UVB intake), aerotherapy (beneficial influence of fresh air on an individual resting outdoors in the shade) and terrain therapy (based on dynamic exercise outdoors) (Ponikowska, 2015). The most commonly used forms of terrain therapy are: walking, jogging, nordic walking and recreational cycling (Koźmiński et al., 2013).

For climatotherapeutic treatments to effectively support other forms of health resort treatment, local biothermal conditions should be conducive to preservation of the organism's thermal balance while straining the human thermoregulation system as little as possible (Kuchcik et al., 2013). In conditions of thermal stress, thermoregulation mechanisms are triggered, requiring significant energy expenditure to maintain a constant core body temperature (Hill et al., 2013). As a result, individuals may experience discomfort, fatigue and reduced capacity to perform various physical activities (Vanos et al., 2010), which may delay the body's regeneration process or even negatively impact patients' health. Furthermore, during short exposures to a hot environment, older people and patients with chronic disease or poor fitness more frequently experience increased levels of thermal strain, as a result of impairments in their sudomotor and vasomotor capacity to dissipate excessive heat (Stapleton et al., 2013; Kenny \& Flouris, 2014).

Although the thermal environment has an unquestionable effect on human body temperature, metabolic heat production is a very important source of heat for the body. Heat is produced through oxidation of organic compounds in the body's cells or via anaerobic metabolism within the skeletal muscles (Guyton \& Hall, 2006; Błażejczyk $\&$ Kunert, 2011). The resting metabolic rate (RMR) of an individual seated calmly in a thermoneutral environment involves an energy expenditure of up to $1.0 \mathrm{kcal} \cdot \mathrm{kg}^{-1} \cdot \mathrm{h}^{-1}$ (depending on age, sex, and obesity status) (McMurray et al., 2014). As a simplification, RMR is often identified with the value of $1 \mathrm{MET}$
(Metabolic Equivalent), which is a physiological concept commonly used to express energy costs of different levels of physical activity (Byrne et al., 2005; Heydenreich et al., 2019). During physical exercise metabolic heat production rises, as contracting muscles require constant energy supply to perform their work (Kenny \& Flouris, 2014). For various forms of physical activities approximated MET levels can be assigned by multiplying standard RMR values, as has been done in Appendix A of ISO 8996 standard (ISO 8996, 2004) or in the Compendium of Physical Activities by Ainsworth (Ainsworth et al., 2011). Although these values often overestimate the real energy cost of physical activity and are not equally applicable to each population group (Byrne et al., 2005), the MET system is commonly used by researchers and clinicians, as it provides much needed standardisation of metabolic heat production for different human activities in research (Ainsworth et al., 2000).

In applied bioclimatology, biometeorological indicators based on the human heat balance models are often used, such as Physiologically Equivalent Temperature (PET), Physiological Subjective Temperature (PST), Perceived Temperature (PT) and many others (Błażejczyk et al., 2012). Given ranges of these indicators' values have been assigned corresponding thermal sensations, which facilitates the interpretation of results and allows some degree of comparability. However, the applicability of thermal sensation scales is strictly limited in the case of individuals' varying physical activity, as the scales are only valid for the assumed values of metabolic heat production (Matzarakis et al., 1999): $80 \mathrm{~W} \cdot \mathrm{m}^{-2}$ in PET (Höppe, 1999) and $135 \mathrm{~W} \cdot \mathrm{m}^{-2}$ in PST (Błażejczyk \& Matzarakis, 2007) or PT (Staiger et al., 2012). The Universal Thermal Climate Index (UTCI) provides a thermal stress assessment scale (Tab. 1), where the boundaries of individual classes are defined by significant changes in physiological parameters, which are the thermoregulation system's response to changing thermal conditions (Błażejczyk et al., 2013). 
Table 1. UTCI values $\left({ }^{\circ} \mathrm{C}\right)$ categorized in terms of thermal stress (according to Błażejczyk et al., 2013)

\begin{tabular}{|c|l|}
\hline $\begin{array}{c}\text { UTCI }\left[{ }^{\circ} \mathrm{C}\right] \\
\text { range }\end{array}$ & \multicolumn{1}{|c|}{ Thermal stress category } \\
\hline$>46.0$ & extreme heat stress \\
38.1 to 46.0 & very strong heat stress \\
32.1 to 38.0 & strong heat stress \\
26.1 to 32.0 & moderate heat stress \\
9.1 to 26.0 & no thermal stress \\
0.1 to 9.0 & slight cold stress \\
-13.0 to 0.0 & moderate cold stress \\
-27.0 to -13.1 & strong cold stress \\
-40.0 to -27.1 & very strong cold stress \\
$<-40.0$ & extreme cold stress \\
\hline
\end{tabular}

For an actual meteorological environment, UTCl is defined as the air temperature of a reference environment yielding an equivalent dynamic physiological response (Bröde al., 2012; Fiala et al., 2012). The reference environment is defined with $50 \%$ relative humidity (but vapour pressure capped at $20 \mathrm{hPa}$ ), with calm air (wind speed $0.5 \mathrm{~m} \cdot \mathrm{s}^{-1}$ measured $10 \mathrm{~m}$ above ground) and mean radiant temperature equalling air temperature. UTCl assumes that the reference person is wearing a clothing ensemble with thermal insulation as observed for the general urban population (Havenith et al., 2012), where the insulation is behaviourally adapted dependent on the air temperature and reduced by wind and walking speed. The reference person is engaged in moderate outdoor activity (walking at a speed of $4 \mathrm{~km} \cdot \mathrm{h}^{-1}$ ), which is associated with constant metabolic rate of 2.3 MET (135 W·m²) (Bröde et al., 2012). However, the flexibility of the UTCI-Fialamodel (Fiala et al., 2012) and universality of the UTCI physiologically based assessment scale make it possible to expand the UTCI to cover a wider range of human activity levels. The procedure of adjustment of UTCI values for different metabolic rates recently introduced by Bröde et al. (2016) creates new opportunities for the comprehensive assessment of bioclimatic conditions and thermal stress risk during various physical activities.
The aim of this paper is the evaluation of biothermal conditions in the selected Polish health resorts depending on different levels of metabolic heat production generated during the most popular forms of climatic therapy. For this purpose an adjusted UTCI was used, which takes into account the impact of different activity levels on human thermal balance.

\section{Materials and methods Study area and data}

For the purposes of this study, three Polish towns with health resort status were selected: Kołobrzeg, Busko-Zdrój and Krynica-Zdrój, representing coastal, lowland and highland resorts respectively. Kołobrzeg is a resort located on the Baltic Sea in the Zachodniopomorskie province, within the Coastal bioclimatic region (Błażejczyk, 2004). This area is characterised by gentle thermal and humidity conditions in summer and the occurrence of highspeed winds, which make it a high-stimulus climate. Busko-Zdrój lies in the Małopolska Upland in the Świętokrzyskie province, in the Upland bioclimatic region. Favourable solar and thermal conditions are present here, and the basic therapeutic resource is sulfide and iodide-bromide waters. Krynica-Zdrój is a highland resort located in a valley in the Beskid Sadecki range in the Małopolskie province, part of the Carpathian bioclimatic region. It is characterised by high climate stimuli and frequent occurrence of air temperature inversion and atmospheric calm (Kozłowska-Szczęsna et al., 2002).

The basis for the study were meteorological data from measurement stations in Kołobrzeg $\left(15^{\circ} 34^{\prime} 50^{\prime \prime} \mathrm{E}, 54^{\circ} 10^{\prime} 58^{\prime \prime} \mathrm{N}\right)$, Busko-Zdrój $\left(50^{\circ} 27^{\prime} \mathrm{N}, 20^{\circ} 42^{\prime} \mathrm{E}\right)$ and Krynica-Zdrój $\left(20^{\circ} 58^{\prime} \mathrm{E}, 49^{\circ} 25^{\prime} \mathrm{N}\right)$ in the decade 2008-2017; however, gaps in data from Krynica-Zdrój in the last two months of 2017 were supplemented by data from the neighbouring Institute of Meteorology and Water Management (IMGW-PIB) station in Wysowa-Zdrój $\left(21^{\circ} 11^{\prime} \mathrm{E}, 49^{\circ} 26^{\prime} \mathrm{N}\right)$. The analysis used daily values of meteorological elements at 12 UTC: 
air temperature $\left(\mathrm{t}-{ }^{\circ} \mathrm{C}\right)$ and relative humidity ( $f-\%)$, wind speed $10 \mathrm{~m}$ above ground $\left(v-m \cdot s^{-1}\right)$ and total cloud cover ( $N$ - octas). Table 2 summarizes the climatic conditions in the studied areas during period 2008-2017. Next, using the MENEX_2005 model in BioKlima 2.6 (available at https://www. igipz.pan.pl/Bioklima-zgik.html) the values of mean radiant temperature $\left(\mathrm{t}_{\mathrm{mrt}}-{ }^{\circ} \mathrm{C}\right)$ were calculated, reflecting the impact of all longand short-wave radiant fluxes on the human body in a given environment. Establishing the value of this index is crucial for the proper determination of the human radiation budget (Kántor \& Unger, 2011). The above parameters were used to determine the degree of thermal stress for the human organism, as defined using the UTCI (Universal Thermal Climate Index). UTCI values at 12 UTC were calculated in BioKlima 2.6 in accordance with the original operational procedure (Bröde et al., 2012), which assumes a moderate activity level $\left(135 \mathrm{~W} \cdot \mathrm{m}^{-2}=2.3 \mathrm{MET}\right)$ and exposure time of 2 hours. The results were averaged over the decades (10-day periods) of the month, where each third decade of the month had 8-11 days.
To preserve the thermal balance of the human organism during exercise, the thermal properties of clothing layers covering the body (mainly thermal insulation) are significant, as clothing forms an important barrier to heat transfer and evaporation from the body surface (Gavin, 2003). In this study the adaptive clothing model (Havenith et al., 2012), incorporated into the UTCl operational procedure, was applied. This model takes into account specific features of the urban population's typical dressing behaviour and changes in isolation properties of clothing depending on actual air temperature. For the purposes of this study it was assumed that clothing worn by patients in Polish health resorts does comply with the thermal properties assumed by the UTCl-clothing model (Havenith et al., 2012).

The human physiological response to the thermal environment is also modified by changing exposure duration, as the response of the thermoregulatory system changes over time due to thermal adaptation processes (Fiala \& Havenith, 2015). In this paper, as assumed in the original operational procedure for UTCl calculation (Bröde et al.,

Table 2. Yearly mean values \pm standard deviations of air temperature $(\mathrm{t})$, relative humidity $(\mathrm{f})$, wind speed $10 \mathrm{~m}$ above ground (v) and total cloud cover (N) at 12 UTC in the studied areas in years 2008-2017

\begin{tabular}{|l|c|c|c|c|}
\hline & $\begin{array}{c}\mathrm{t} \\
{\left[{ }^{\circ} \mathrm{C}\right]}\end{array}$ & $\begin{array}{c}f \\
{[\%]}\end{array}$ & $\begin{array}{c}\mathrm{v} \\
{\left[\mathrm{m} \cdot \mathrm{s}^{-1}\right]}\end{array}$ & $\begin{array}{c}\mathrm{N} \\
{[\text { octas }]}\end{array}$ \\
\hline Kołobrzeg & $11.0 \pm 7.8$ & $74.3 \pm 14.1$ & $3.1 \pm 1.3$ & $5.5 \pm 2.5$ \\
Busko-Zdrój & $12.7 \pm 9.8$ & $65.0 \pm 18.6$ & $3.2 \pm 2.3$ & $5.6 \pm 2.7$ \\
Krynica-Zdrój & $10.7 \pm 9.5$ & $70.8 \pm 19.2$ & $2.7 \pm 1.6$ & $5.1 \pm 2.5$ \\
\hline
\end{tabular}

\section{Adjusted $\mathrm{UTCl}$ as an indicator of patients' thermal balance}

Additive adjustment terms for UTCI ( $\triangle \mathrm{UTCl})$ were calculated as explained below in order to allow for the metabolic rate changes during different forms of climatic therapy. Values of metabolic heat production for typical activities performed by health resort patients (Tab. 3) were estimated from the ISO Standard (ISO 8996, 2004) and Compendium of Physical Activities (Ainsworth et al., 2011).
2012), the 2-hour time of exposure to particular biothermal conditions was used in all simulations.

Additive adjustment terms ( $\triangle \mathrm{UTCl})$ and adjusted values of UTCI $\left(\mathrm{UTCl}_{\text {adj }}=\mathrm{UTCl}+\right.$ $\triangle \mathrm{UTCl}$ ) were available from earlier calculations following the procedure proposed by Bröde et al. (2016, 2017), which is briefly described below.

The additive adjustment values ( $\triangle \mathrm{UTCl}$ ) for UTCl had been calculated considering the range of physical activity from resting (1.1 
MET) to a very high level (4.9 MET) of metabolic heat production, with intermediate activity levels set at 1.7, 2.3, 2.8, and 3.9 MET.

Table 3. Metabolic heat production for different forms of climatic therapy (estimated according to ISO 8996, 2004 and Ainsworth et al., 2011)

\begin{tabular}{|c|c|c|}
\hline \multirow{2}{*}{ Activities } & \multicolumn{2}{|c|}{ Metabolic rate } \\
\hline & MET & $\mathrm{W} \cdot \mathrm{m}^{-2}$ \\
\hline $\begin{array}{l}\text { Heliotherapy } \\
\text { (resting in sitting or standing } \\
\text { position) }\end{array}$ & 1.1 & 65 \\
\hline Terrain therapy: & & \\
\hline $\begin{array}{l}\text { Slow walk } \\
\text { (on even path, without load, } \\
\text { at } 3-4 \mathrm{~km} \cdot \mathrm{h}^{-1} \text { ) }\end{array}$ & 2.3 & 135 \\
\hline $\begin{array}{l}\text { Fast walk } \\
\text { (on even path, without load, } \\
\text { at } \sim 5 \mathrm{~km} \cdot \mathrm{h}^{-1} \text { ) }\end{array}$ & 3.4 & 200 \\
\hline $\begin{array}{l}\text { Marching } \\
\text { (on even path, without load, } \\
\text { at } \sim 5.5 \mathrm{~km} \cdot \mathrm{h}^{-1} \text { ) }\end{array}$ & 4.0 & 235 \\
\hline $\begin{array}{l}\text { Bicycling } \\
\text { (for pleasure, on flat terrain, } \\
\text { at }<16 \mathrm{~km} \cdot \mathrm{h}^{-1} \text { ) }\end{array}$ & & \\
\hline $\begin{array}{l}\text { Nordic walking } \\
\text { (for exercise, on flat terrain, } \\
\text { at } 5-6 \mathrm{~km} \cdot \mathrm{h}^{-1} \text { ) }\end{array}$ & 4.8 & 280 \\
\hline
\end{tabular}
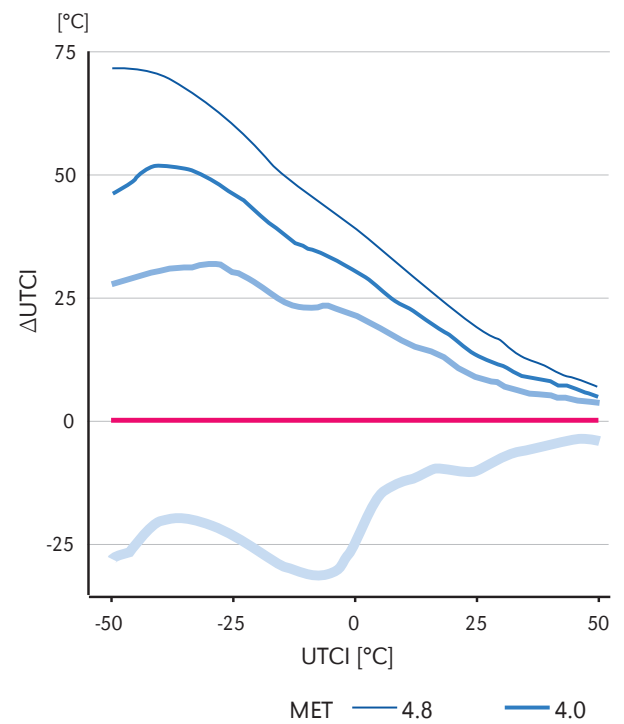

Air temperatures varied from $-50^{\circ} \mathrm{C}$ to $+50^{\circ} \mathrm{C}$ with a step size of $1^{\circ} \mathrm{C}$ for $\mathrm{UTCl}$ reference climatic conditions as defined above, and exposure duration was fixed to 2 hours conforming to the UTCl reference (Bröde et al., 2012). Simulations were performed with the UTCl-Fiala model (Fiala et al., 2012) using the adaptive UTCl-clothing model (Havenith et al., 2012). For the 606 combinations of air temperature and activity level UTCI values were derived from the model output as in the original calculations. By subtracting UTCI for the reference conditions, which are equal to air temperature by definition (Bröde et al., 2012), from these calculated values, a two-dimensional grid of $\triangle \mathrm{UTCl}$ values depending on UTCl and activity level (MET) was obtained.

For combinations of MET and UTCI in our study, $\Delta U T C l$ values which did not coincide with the pre-calculated grid, MET and UTCI values were calculated for our data by a linear two-dimensional interpolation procedure ("interp2") provided by the pracma package (Borchers, 2019) using version 4.0.2 of $\mathrm{R}$ (R Core Team, 2020). In order to obtain UTCl ${ }_{\text {adj }}$ values, the adjustment terms $(\triangle \mathrm{UTCl})$ were

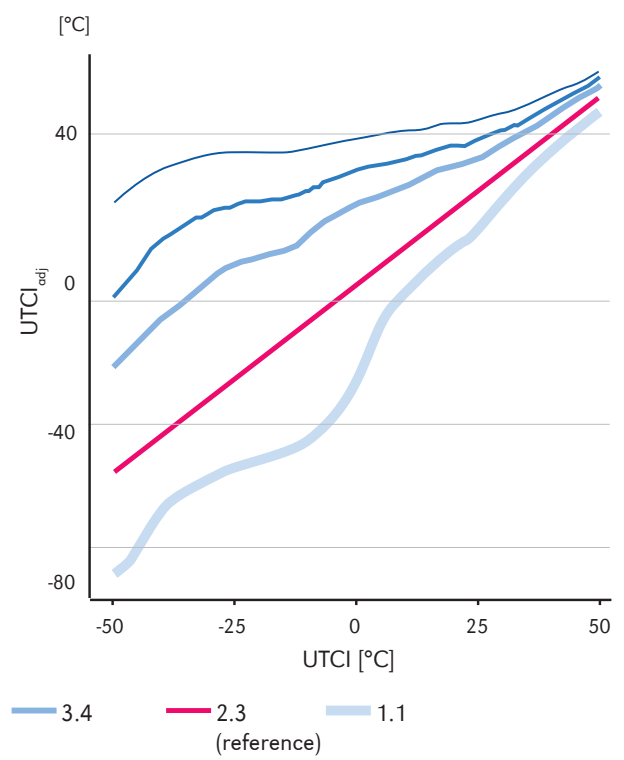

Figure 1. Adjustment values $(\triangle \mathrm{UTCl})$ and adjusted $\mathrm{UTCl}\left(\mathrm{UTCl} \mathrm{adj}_{\mathrm{aj}}=\mathrm{UTCl}+\Delta \mathrm{UTCl}\right)$ related to $\mathrm{UTCl}$ and MET 
added to the reference UTCI values calculated for our data in BioKlima 2.6. The received results were interpreted using the widely known UTCl assessment scale of thermal stress categories ranging from extreme cold to extreme heat stress as shown in Table 1 (Błażejczyk et al., 2013). The adjustment terms $(\triangle \mathrm{UTCl})$ together with $\mathrm{UTCl}_{\text {adj }}$ values related to UTCI for our MET conditions are displayed by Figure 1.

\section{Results}

In the years 2008-2017 the average 10-day values of $\mathrm{UTCl}$ in the health resorts in question varied from $-8.4^{\circ} \mathrm{C}$ (Fig. 2) in January in BuskoZdrój to $27.9^{\circ} \mathrm{C}$ in August, also in Busko-Zdrój, which indicates the occurrence of thermal strain from moderate cold stress to moderate heat stress during calm walks (2.3 MET). The greatest variability in biothermal conditions was observed from May to August. In this period, the coastal resort in Kołobrzeg was characterised by distinctly lower UTCI values, while the highest heat stress was noted in the lowland resort in Busko-Zdrój. UTCI values were the most similar in all the stations in September and October.

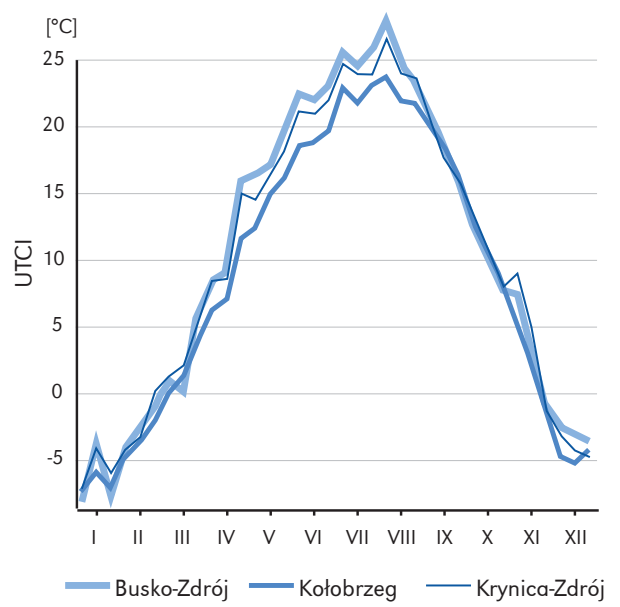

Figure 2. Annual course of mean UTCl values at 12 UTC for standard moderate physical activity (2.3 MET) in Kołobrzeg, Busko-Zdrój and Krynica-Zdrój averaged over 10-day periods in the years 2008-2017
In the analysed period, cold stress of a varying intensity during moderate physical activity (2.3 MET) occurred the most often in Kołobrzeg, particularly in December and January (Fig. 3), and in over $70 \%$ of cases this was moderate cold stress. At the same time, only in the coastal resort very strong cold stress did not appear at all in winter. Meanwhile, heat stress was most frequently observed in Polish resorts in the first 10 days of August. In this period, in Kołobrzeg heat stress appeared on $36 \%$ of days, in Busko-Zdrój, on $62 \%$ and in Krynica-Zdrój, on 51\%. Patients in Busko-Zdrój were exposed to the greatest heat load, as very strong heat stress was present there on $3 \%$ of summer days. For the health and well-being of patients (particularly the elderly and convalescents) thermoneutral conditions that do not overly strain the human body are the most favourable. A lack of thermal stress was observed most frequently in the coastal resort in Kołobrzeg, particularly in periods from the last part of May to the end of June and from the 11th of August to the end of September (at least $80 \%$ of days). All of the above indicates less variation in biothermal conditions on the Baltic coast than in the remaining parts of the country.

After adjustment of UTCl values, differing characteristics were obtained for thermal stress in Polish health resorts after 2 hour exposition and depending on the intensity of physical activity (Fig. 4). As expected, with increasing metabolic heat production, $\mathrm{UTCl}_{\text {adj }}$ values in the given biothermal conditions rose compared to Figure 2, indicating growing heat stress. At the same time, with the increase in physical exertion intensity, the regional differences in thermal load in the analysed locations decreased. In the case of heliotherapy, the form of climatic therapy with the lowest energy expenditure for the patient's body (1.1 MET), the 10-day averages of UTCl ${ }_{\text {adj }}$ values at 12 UTC varied from $-36.3^{\circ} \mathrm{C}$ in the first 10 days of January in Kołobrzeg to $20.0^{\circ} \mathrm{C}$ in the beginning of August in Busko-Zdrój. This means that in winter in all three resorts patients undergoing heliotherapy experienced very strong 


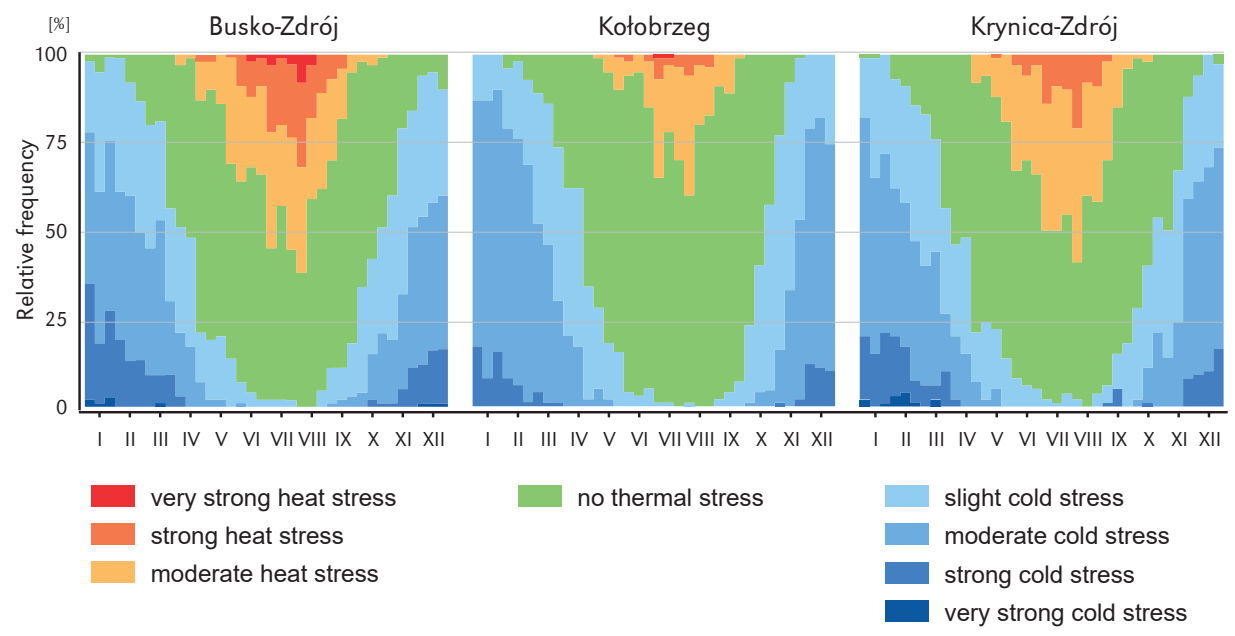

Figure 3. Annual course of compositional relative frequency (\%) of thermal stress categories based on UTCl values at 12 UTC for standard moderate physical activity (2.3 MET) in Kołobrzeg, Busko-Zdrój and Krynica-Zdrój averaged over the years 2008-2017

Note: both extreme cold and heat stress did not occur.
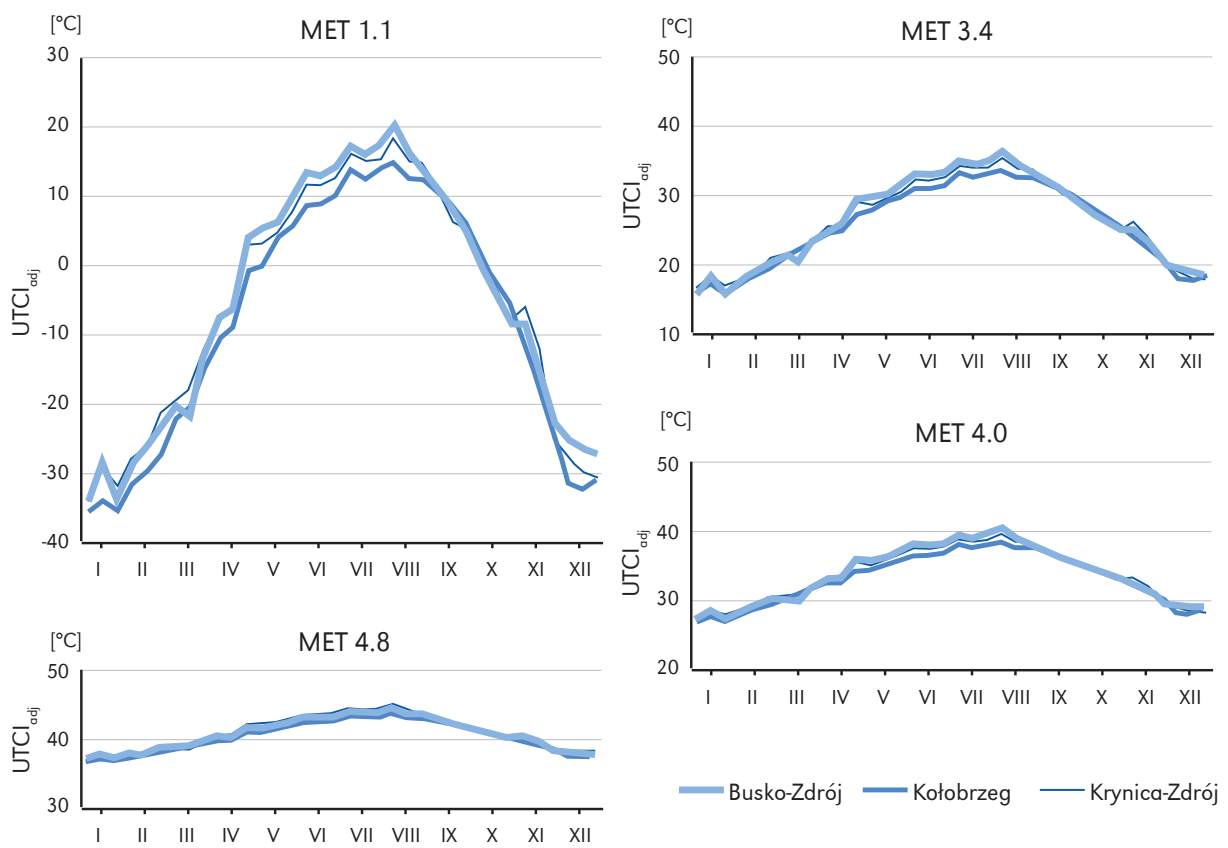

Figure 4. Annual course of mean UTCl ${ }_{\text {adj }}$ values at 12 UTC for various physical activity levels in Kołobrzeg, Busko-Zdrój and Krynica-Zdrój averaged over 10-day periods in the years 2008-2017 
cold stress, while in summer heat stress did not occur during these treatments. When the level of metabolic production rose during terrain therapy, UTCl ${ }_{\text {adj }}$ values indicated that over the whole year, cold stress was not observed in any of the stations, but heat load became a problem, with highest intensity in Busko-Zdrój at the start of August. In the case of fast walks (3.4 MET) in the warmest period of the year at 12 UTC strong heat stress $\left(\mathrm{UTCl}_{\mathrm{adj}}=36.4^{\circ} \mathrm{C}\right)$ occurred, while during marching or calm bicycle rides (4.0 MET) and moderately intensive Nordic walking (4.8 MET) patients experienced very strong heat stress $\left(40.6^{\circ} \mathrm{C}\right.$ and $45.5^{\circ} \mathrm{C}$ respectively).

The most desirable conditions for climatotherapeutic treatments are those that do not strain the human body. In the case of low physical activity (1.1 MET) during heliotherapy, situations without thermal load at 12 UTC occurred in the studied resorts mainly in the warm half of the year (Fig. 5). In summer months (VI-VIII), according to $\mathrm{UTCl}_{\text {adj }}$ values, no thermal stress was observed with a frequency from 61\% of days in Busko-Zdrój to $68 \%$ in Krynica-Zdrój. The highest share of days conducive to heliotherapy fell in the last days of July and at the end of August in Kołobrzeg (75\% each). The most favourable biothermal conditions for terrain therapy with moderate physical activity (3.4 MET) occurred in Polish resorts from autumn to spring. Thermoneutral conditions, as indicated by the 'no thermal stress' category, conducive to intensive walks were most often observed in winter (DecemberFebruary): from 79\% of days in Busko-Zdrój to $83 \%$ of days in Kołobrzeg, with a maximum of $95 \%$ of cases occurring at the end of December in Kołobrzeg. In the case of more intensive terrain therapy, that generates higher metabolic heat rates, the share of days in the year with no thermal stress decreases significantly. At a physical activity level of 4.0 MET, 'no thermal stress' conditions are limited only to the cold half of the year, with a maximum in January - from 32\% of days per month in Krynica-Zdrój to 38\% in Busko-Zdrój. When intensity of terrain therapy rose to the level of 4.8 MET, situations with no thermal stress at 12 UTC were not observed in any of the three locations.

In the resorts in question, patients undergoing heliotherapy were exposed to cold stress for a significant part of the year. In winter, low metabolic heat production (1.1 MET) was most frequently accompanied by very strong and extreme cold stress, accounting for $76 \%$ of all days in Kołobrzeg to $57 \%$ of days in Busko-Zdrój (Fig. 5). The most intense situations of extreme cold stress, which can cause frostbite in the case of insufficient clothing insulation and limited physical activity, appeared in Busko-Zdrój and Krynica-Zdrój from October to the end of April, and in Kołobrzeg from November to the end of March (Fig. 5). Most frequently (> $40 \%$ of days) such strong cold strain on the body was observed in the first and last third of January in Busko-Zdrój.

However, the factor impeding terrain therapy in Polish resorts was heat stress, which increases with the intensification of physical activity. During intensive walks (3.4 MET) patients could sometimes experience very strong heat stress from May (and in Busko-Zdrój already from the last days of April) to the middle part of September. In this period it was the least frequent in Kołobrzeg (3\% of days), and most frequent in Busko-Zdrój (14\%). When physical activity increased in intensity to 4.0 MET, the share of situations of very strong heat stress grew significantly, even up to $71 \%$ in Krynica-Zdrój in the first 10 days of August. At the same time, in summer months at 12 UTC during recreational bicycle rides patients in Kołobrzeg and Busko-Zdrój could experience single cases of extreme heat stress, which are related to increased risk of dehydration and heat stroke. During further intensification of physical exercise, strong or greater heat load was present in all resorts over the whole year. According to $\mathrm{UTCl}_{\text {adj }}$ during metabolic heat production of $4.8 \mathrm{MET}$, hazardous to health extreme heat stress appeared in the warm half of the year (April to September) - most often in Busko-Zdrój (on 12\% of days). 

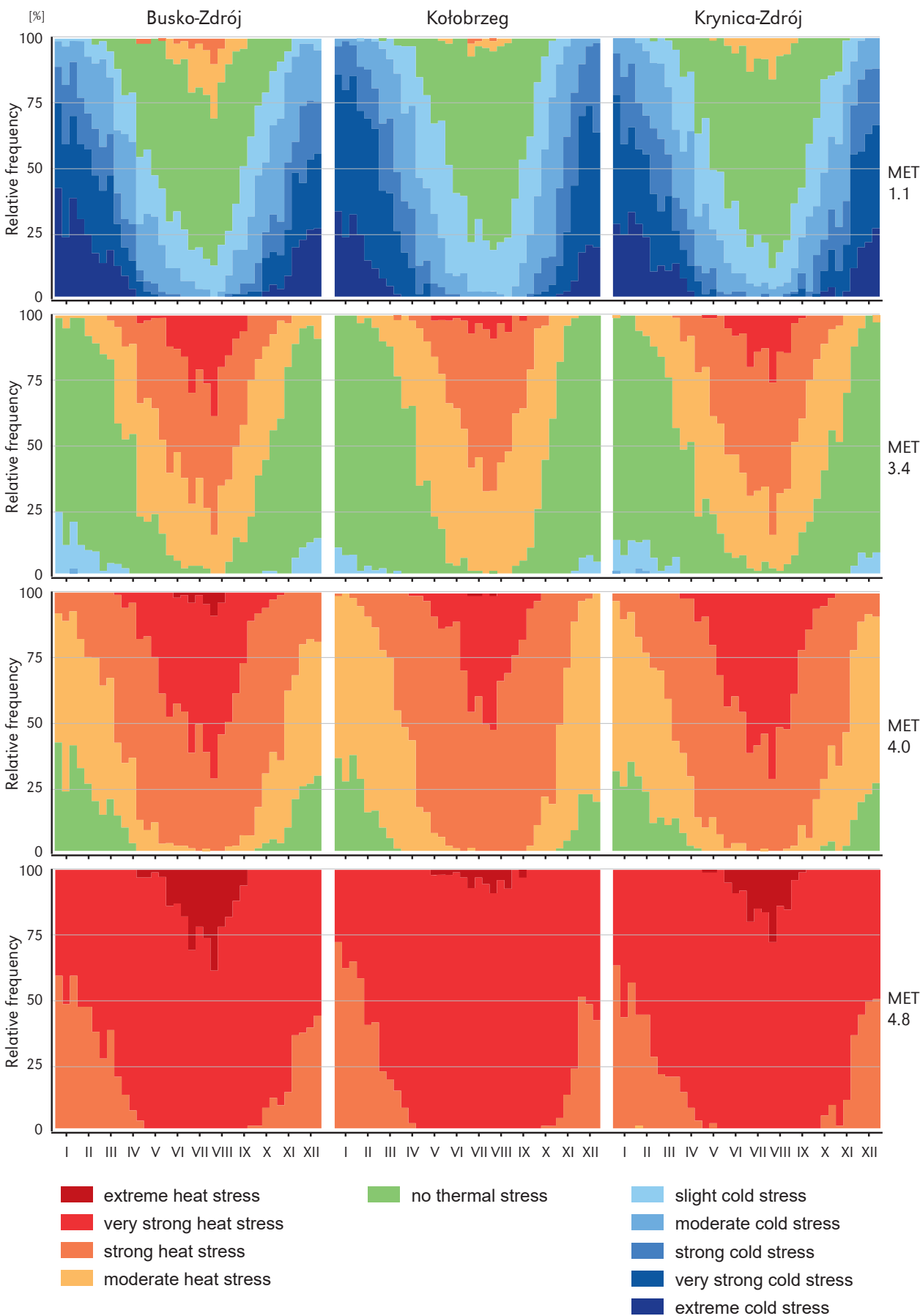

Figure 5. Annual course of compositional relative frequency (\%) of thermal stress categories according to UTCl ${ }_{\text {adj }}$ at 12 UTC for various physical activity levels in Kołobrzeg, Busko-Zdrój and Krynica-Zdrój averaged over the years 2008-2017 


\section{Discussion}

The results obtained for the UTCl in the selected health resorts confirmed that in Poland at 12 UTC 'no thermal stress', i.e. thermoneutral conditions prevailed over the course of the year (from $40 \%$ in Busko-Zdrój to $44 \%$ in Kołobrzeg), which remains in accordance with results of previous studies(Błażejczyk \& Kunert, 2011; Kuchcik, 2017; Kolendowicz et al., 2018). At the same time, in all stations cold stress of varying intensity was observed more often than heat stress. It was also confirmed that coastal resorts (represented in this study by Kołobrzeg) are the most privileged in thermal terms, as in the warm half of the year they have the most days in Poland with thermoneutral conditions (Kuchcik et al., 2013). Furthermore, in summer the Baltic coast is the coolest and most windy region of Poland (apart from highmountain areas) (Krzyżewska et al., 2020), which is reflected in the lowest frequency of strong heat stress in this region. In winter, meanwhile, cold stress occurred in Kołobrzeg far less often than in Busko-Zdrój and Krynica-Zdrój, while very strong cold stress was not observed there at all. However it should be noted that in winter UTCl values on the Polish coast decrease from west to east, and thus the degree of strain from cold stress in resorts in the western part of the coast is lower than in the Hel peninsula area (Koźmiński \& Michalska, 2019). Strong heat stress most often (4\% of days) appeared and lasted the longest (from the end of April to mid-September) in the south-east part of the country, in Busko-Zdrój, which confirms that the Upland Region is the warmest bioclimatic region of Poland (Krzyżewska et al., 2020). Very strong heat stress was only sporadically observed in the studied resorts, and in the highland resort of Krynica-Zdrój it was not recorded even once.

The UTCl adjustment procedure enabled determination of the optimum periods for different types of climate therapy for Polish health resorts. Treatments associated with a low metabolic rate, such as heliotherapy
(1.1 MET), could be conducted with thermal comfort maintenance on most days (at least $50 \%$ ) uninterruptedly from the last days of April to the middle part of October on the coast in Kołobrzeg, and in Busko-Zdrój over the same period with the exception of July and first 10 days of August. Biothermal conditions favourable for heliotherapy were present the longest in the highland resort of Krynica-Zdrój: from the start of April to the middle of October, excluding only the beginning of August. However, it should be mentioned that in mountain and foothill areas, the suitability of the local bioclimate for heliotherapy is spatially differentiated and strongly dependent on altitude, exposition of the slopes and topographic orientation of the valleys, due to significant impact of the relief on the access of solar radiation (Kozłowska-Szczęsna et al., 2004). Furthermore, the use of heliotherapy in the highland health resorts, where UV radiation absorption is greater due to reduced optical thickness of the atmosphere (Kuchcik et al., 2013) and additionally significant amount of solar radiation is being reflected from snow cover, require appropriate protective measures to reduce the risk of skin cancer (Koo \& Nakamura, 2017).

In Poland, terrain therapy is mostly constrained by heat stress, which grows with physical activity and which may, particularly during hot summer days in lowland and highland resorts, endanger patients, leading to significant thermoregulatory load (Krawczyk, 2001). This is confirmed in our results, as for a metabolic rate of around 3.4 MET the best biothermal conditions (at least $50 \%$ days with no thermal stress) occurred from the last days of October to the middle of April. For more intensive exercise, such as marching or recreational bicycling (4.0 MET, Tab. 3), thermoneutral ('no thermal stress') conditions were observed in the analysed locations only in the cool half of the year, on $7-11 \%$ of days in the year. This was in contrast to the conclusions of Błażejczyk et al. (2020), who found weather in Poland from September to April to be very suitable for active recreation in an analysis applying the Weather Suitability 
Index (WSI). This metric includes components related to thermal sensation, but also elements of the weather (precipitation, snow cover), which determine the attractiveness of particular atmospheric conditions for tourists (Błażejczyk, 2007; Błażejczyk \& Matzarakis, 2007; Błażejczyk \& Kunert, 2011), and thus differs from the UTCl approach, which focusses on the thermal strain of the human organism.

For activities at 4.8 MET, regional differences were erased and for most of the year very strong heat stress, possibly associated with health risks, occurred. However, these results may be less accurate than the predictions of the Fiala model obtained for lower activity levels, as when subjects exercise heavily, non-thermal factors like e.g. fitness level may play a significant role and impact $\mathrm{UTCl}_{\text {adj }}$ values (Fiala et al., 2001). Furthermore, in this study 2-hour exposure time was assumed, which resulted in relatively high thermal stress rates, that could be diminished by shortening the duration of workout sessions, especially in the cold environment (Bröde et al., 2017).

While focussing on the influence of activity levels differing from the UTCI reference level (2.3 MET), it should be noted that some examples from Table 3 additionally deviate in other aspects from the UTCl assumptions. E.g., whereas the body movement for 'marching' from the 4 MET activity level comes close to the $4 \mathrm{~km} \cdot \mathrm{h}^{-1}$ walking speed assumed for the UTCl person, cycling with $16 \mathrm{~km} \cdot \mathrm{h}^{-1}$ will appreciably increase convective heat loss due to exposure to higher relative air velocity, which is a composite of movement speed and wind speed (ISO 9920, 2007). Similarly, when resting, as assumed for heliotherapy (1.1 $\mathrm{MET}$ ), convective heat loss will be lower than for the modelled walking person, thus reducing cold stress while enhancing heat stress. Relative air velocity as calculated by the UTCI model (Havenith et al., 2012) for a walking person in a direction-independent manner according to ISO 9920 (2007) exceeds wind speeds below walking speed $\left(1.1 \mathrm{~m} \cdot \mathrm{s}^{-1}\right)$. However, this discrepancy becomes negligible for $v>2 \mathrm{~m} \cdot \mathrm{s}^{-1}$ (measured $10 \mathrm{~m}$ above ground), which prevailed in more than $75 \%$ of all measured conditions. This might suggest a limited influence of this effect concerning heliotherapy settings in this study.

For cycling with $16 \mathrm{~km} \cdot \mathrm{h}^{-1}$, however, more than $95 \%$ of all wind speeds measured $10 \mathrm{~m}$ above ground were below $v=6.5 \mathrm{~m} \cdot \mathrm{s}^{-1}$, the value corresponding to this movement speed. Therefore, we approximately evaluated the influence of this increased body movement by recalculating $\mathrm{UTCl}_{\text {adj }}$ using $v=6.5 \mathrm{~m} \cdot \mathrm{s}^{-1}$ in all cases with lower measured wind speeds. The resulting profiles depicted in Figure 6 indicate that the frequency of heat stress decreased due to cycling with $16 \mathrm{~km} \cdot \mathrm{h}^{-1}$ for the $4 \mathrm{MET}$ condition, but also for 3.4 MET and 2.3 MET, in comparison to the results from Figures $3 \& 5$. They also suggest that, concerning this setting, adaptively reducing the activity level, e.g. by using electric assisted bicycles (Berntsen et al., 2017) would help to achieve thermoneutral ('no thermal stress') conditions for almost the whole year.

As another element of human behavioural thermoregulation (Schlader et al., 2010) besides adapting the activity level, thermal stress that appears during various forms of climatotherapy may partly be reduced by choosing clothing with higher or lower thermal insulation than assumed in the UTCI clothing model (Havenith et al., 2012). More specifically, the model does not consider behavioural clothing adjustments, e.g. taking off headwear, scarves, and gloves or opening jackets when experiencing heat strain while exercising in winter clothing. However, options for such modifications with respect to heat stress are significantly limited (Lindner-Cendrowska \& Błażejczyk, 2013) and would require using professional sportswear or inadequate clothing that is too revealing by the standards of acceptable dress for resort patients. Meanwhile clothing adjustment for outdoor winter activities is very difficult (Rintamäki \& Rissanen, 2006), as insufficient insulation of garments may lead to hypothermia, while too many clothing layers, while exercising, 

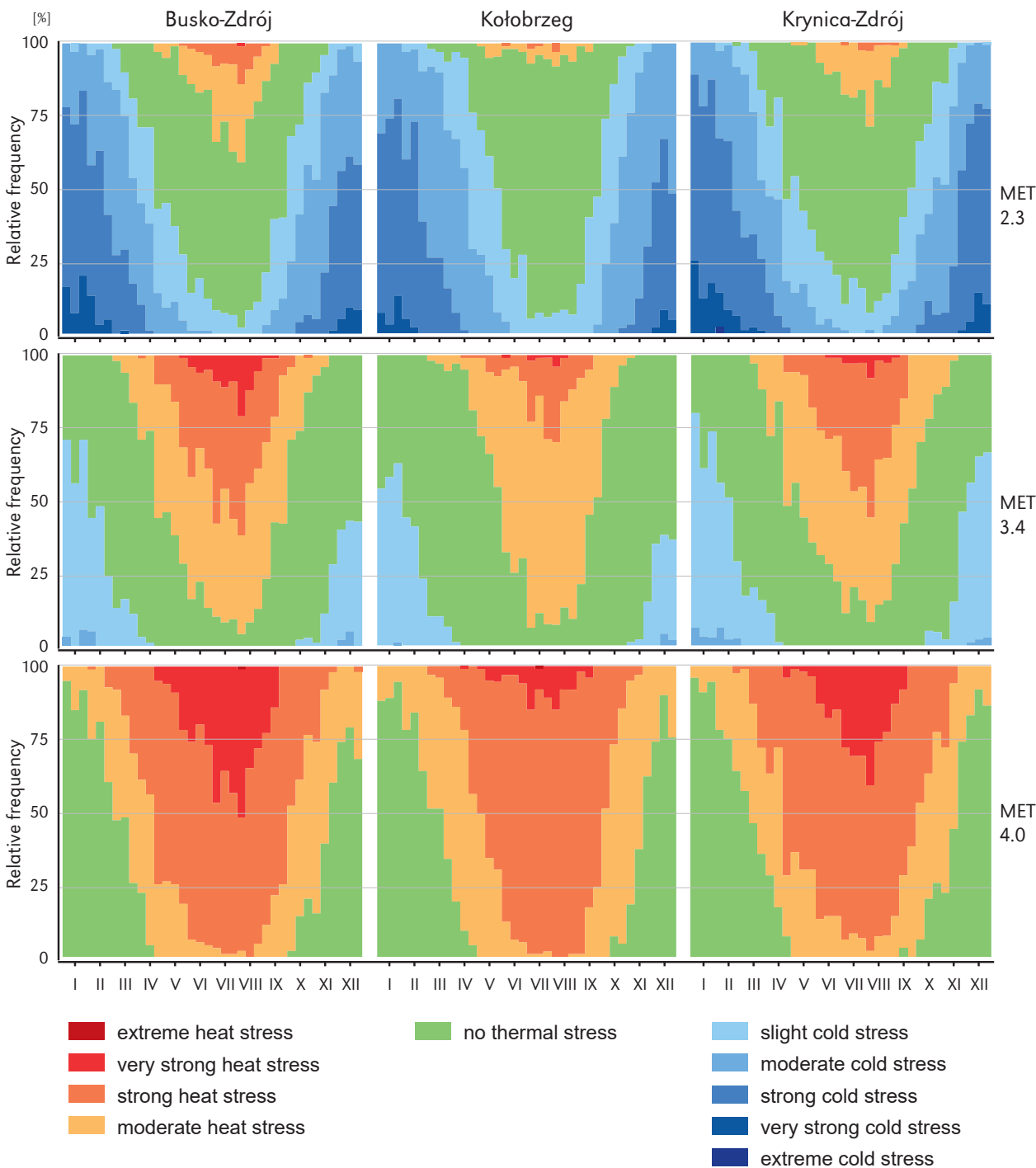

Figure 6. Annual course of compositional relative frequency (\%) of thermal stress categories according to $\mathrm{UTCl}_{\text {adi }}$ at $12 \mathrm{UTC}$ considering the increased relative wind speed due to cycling with $16 \mathrm{~km} \cdot \mathrm{h}^{-1}$ for various physical activity levels in Kołobrzeg, Busko-Zdrój and Krynica-Zdrój averaged over the years 2008-2017

may cause body temperature increase and excessive sweating (Gavin, 2003).

It should also be emphasised that the above analysis considers mean situations with no thermal stress as optimum conditions, which do not cause excessive strain on the human body. However, in the case of healthy individuals, repeated exposure to conditions diverging slightly from the thermoneutral zone can enhance body fitness and endurance capability (Schuh, 1993). Furthermore, biometeorological conditions that are objectively good for health may not necessarily be identical to conditions identified as thermal comfort by health resort visitors (Lindner-Cendrowska \& Błażejczyk, 2018). 
Thus the evaluation of bioclimatic conditions suitability may differ depending on whether subjectively perceived thermal comfort or health aspects are taken into account, and to whom an assessment was addressed (Höppe, 2002).

\section{Conclusions}

The UTCI has already been used to evaluate bioclimate for health resort therapy and recreation purposes in Poland (Błażejczyk \& Kunert, 2011; Kuchcik et al., 2013; Koźmiński \& Michalska, 2019). However, previously applied methodology considered only originally assumed moderate activity of $2.3 \mathrm{MET}$, limiting the applicability of such studies. This approach significantly narrowed the group of potential addressees to individuals walking at a low pace. During active recreation and exercise, rising metabolic rate causes changes in values of physiological parameters (Fiala et al., 2001), which result in different thermal stress outcomes. Unfortunately, it is often disregarded that even in a cold environment, heat strain may occur, as very intensive physical activity can increase metabolic heat production from rest values by ten times or more (Rintamäki \& Rissanen, 2006). Moreover, even passive recreation, characterized by low metabolic heat production, under particular circumstances may also involve a different thermal stress level and thermal comfort assessment than predicted by the standard UTCI procedure (Rutty \& Scott, 2015). Therefore, the need to take into account a wider range of metabolic rates in UTCI is justified. Our study demonstrates that using the UTCI adjustment procedure proposed by Bröde et al. (2016) allows for more detailed and balanced assessment of bioclimatic conditions for various types of climatotherapy. Different types of climatic treatment are associated with different ranges of thermal stress, as well as with different timing throughout the year than obtained using standard UTCI protocol. The results show that bioclimatic conditions in Polish health resorts permit all forms of climatic therapy of an intensity up to 4.0 MET, provided that the treatment types are seasonally adjusted to the changing human thermal strain. Finally, we confirmed that detailed physiological modelling of the UTCl-Fiala model allows modifying the original operational procedure, hence making it more applicable to a wide spectrum of human activity levels in diverse biothermal conditions.

\section{Editors' note:}

Unless otherwise stated, the sources of tables and figures are the authors', on the basis of their own research.

\section{References}

Ainsworth, B., Haskell, W., Herrmann, S., Meckes, N., Bassett, D., Tudor-Locke, C., Greer, J., Vezina, J.W., Whitt-Glover, M., Leon, A. (2011). 2011 Compendium of physical activities: A second update of codes and MET values. Medicine \& Science in Sports \& Exercise, 43(8), 1575-1581. https://doi.org/10.1249/MSS.0b013e31821ece12

Ainsworth, B., Haskell, W., Whitt, M., Irwin, M., Swartz, A., Strath, S., O’Brien, W., Bassett, D., Schmitz, K., Emplaincourt, P., Jacobs, D., Leon, A. (2000). Compendium of physical activities: An update of activity codes and MET intensities. Medicine \& Science in Sports \& Exercise, 32(9), S498-S516. https://doi.org/10.1097/00005768-200009001-00009

Berntsen, S., Malnes, L., Langåker, A., Bere, E. (2017). Physical activity when riding an electric assisted bicycle. International Journal of Behavioral Nutrition and Physical Activity, 14(1), 55. https://doi.org/10.1186/s12966-017-0513-z 
Błażejczyk, A., Pecelj, M., Skrynyk, O., Błażejczyk, K., Skrynyk, O. (2020). Weather suitability for outdoor tourism in three European regions in first decades of the twenty-first century. International Journal of Biometeorology. https://doi.org/10.1007/s00484-020-01984-z

Błażejczyk, K. (2004). Bioklimatyczne uwarunkowania rekreacji i turystyki w Polsce. Prace Geograficzne, 192, Warsaw: IGiPZ PAN.

http://rcin.org.pl/igipz/Content/576/Wa51_3535_r2004-nr192_Prace-Geogr.pdf

Błażejczyk, K. (2007). Weather limitations for winter and summer tourism in Europe. In A. Matzarakis, C.R. de Freitas, D. Scott (Eds.), Developments in Tourism Climatology (pp. 116-121). Commission Climate, Tourism and Recreation, International Society of Biometeorology. http://citeseerx.ist.psu.edu/viewdoc/download?doi=10.1.1.519.7644\&rep=rep1\&type=pdf

Błażejczyk, K., Epstein, Y., Jendritzky, G., Staiger, H., Tinz, B. (2012). Comparison of UTCl to selected thermal indices. International Journal of Biometeorology, 56(3), 515-535. https://doi.org/10.1007/s00484-011-0453-2

Błażejczyk, K., Jendritzky, G., Bröde, P., Fiala, D., Havenith, G., Epstein, Y., Psikuta, A., Kampmann, B. (2013). An introduction to the Universal thermal climate index (UTCI). Geographia Polonica, 86(1), 5-10. https://doi.org/10.7163/GPol.2013.1

Błażejczyk, K., Kunert, A. (2011). Bioklimatyczne uwarunkowania rekreacji i turystyki w Polsce (2nd ed.). Monografie, 13, Warsaw: IGiPZ PAN. http://rcin.org.pl/igipz/Content/19801/WA51_39725_r2011-nr13_Monografie.pdf

Błażejczyk, K., Matzarakis, A. (2007). Assessment of bioclimatic differentiation of Poland based on the human heat balance. Geographia Polonica, 80(1), 63-82. http://rcin.org.pl/igipz/Content/82/Polonica1_2007_30_09_2008.pdf\#page=63

Borchers, H.W. (2019). Pracma: Practical numerical math functions. Retrieved from https://CRAN. 24 R-project.org/package=pracma

Bröde, P., Fiala, D., Błażejczyk, K., Holmér, I., Jendritzky, G., Kampmann, B., Tinz, B., Havenith, G. (2012). Deriving the operational procedure for the Universal Thermal Climate Index (UTCI). International Journal of Biometeorology, 56(3), 481-494. https://doi.org/10.1007/s00484-011-0454-1

Bröde, P., Fiala, D., Kampmann, B. (2017). Considering varying clothing, activities and exposure times with the Universal Thermal Climate Index UTCI. 21st International Congress of Biometeorology. Extended Abstracts, 57-60.

Bröde, P., Kampmann, B., Fiala, D. (2016). Extending the Universal Thermal Climate Index UTCI towards varying activity levels and exposure times. In L. Brotas, S. Roaf, F. Nicol, M.A. Humphreys (Eds.), Making Comfort Relevant, 9th Windsor Conference (pp. 73-79). Network for Comfort and Energy Use in Buildings.

Byrne, N.M., Hills, A.P., Hunter, G.R., Weinsier, R.L., Schutz, Y. (2005). Metabolic equivalent: one size does not fit all. Journal of Applied Physiology, 99(3), 1112-1119. https://doi.org/10.1152/japplphysiol.00023.2004

Fiala, D., Havenith, G., Bröde, P., Kampmann, B., Jendritzky, G. (2012). UTCl-Fiala multi-node model of human heat transfer and temperature regulation. International Journal of Biometeorology, 56(3), 429-441. https://doi.org/10.1007/s00484-011-0424-7

Fiala, D., Lomas, K.J., Stohrer, M. (2001). Computer prediction of human thermoregulatory and temperature responses to a wide range of environmental conditions. International Journal of Biometeorology, 45(3), 143-159. https://doi.org/10.1007/s004840100099

Fiala, D., Havenith, G. (2015). Modelling Human Heat Transfer and Temperature Regulation. In A. Gefen, Y. Epstein (Eds.), The Mechanobiology and Mechanophysiology of Military-Related Injuries (pp. 265-302). Springer, Cham. https://doi.org/10.1007/8415_2015_183

Gavin, T.P. (2003). Clothing and Thermoregulation During Exercise. Sports Medicine, 33(13), 941-947. https://doi.org/10.2165/00007256-200333130-00001

Guyton, A.C., Hall, J.E. (2006). Textbook of Medical Physiology (11th ed.). Elsevier Saunders. https://books.google.pl/books?id=0mdqAAAAMAAJ 
Havenith, G., Fiala, D., Błazejczyk, K., Richards, M., Bröde, P., Holmér, I., Rintamaki, H., Benshabat, Y., Jendritzky, G. (2012). The UTCl-clothing model. International Journal of Biometeorology, 56(3), 461-470. https://doi.org/10.1007/s00484-011-0451-4

Heydenreich, J., Schutz, Y., Melzer, K., Kayser, B. (2019). Comparison of Conventional and Individualized 1-MET Values for Expressing Maximum Aerobic Metabolic Rate and Habitual Activity Related Energy Expenditure. Nutrients, 11(2), 458. https://doi.org/10.3390/nu11020458

Hill, R.W., Muhich, T.E., Humphries, M.M. (2013). City-Scale Expansion of Human Thermoregulatory Costs. PLoS ONE, 8(10), e76238. https://doi.org/10.1371/journal.pone.0076238

Höppe, P. (1999). The physiological equivalent temperature - a universal index for the biometeorological assessment of the thermal environment. International Journal of Biometeorology, 43(2), 71-75. https://doi.org/10.1007/s004840050118

Höppe, P. (2002). Different aspects of assessing indoor and outdoor thermal comfort. Energy and Buildings, 34(6), 661-665. https://doi.org/https://doi.org/10.1016/S0378-7788(02)00017-8

ISO 8996. (2004). Ergonomics of the thermal environment - Determination of metabolic rate.

ISO 9920. (2007). Ergonomics of the thermal environment - Estimation of thermal insulation and water vapour resistance of a clothing ensemble.

Kanayama, H., Kusaka, Y., Hirai, T., Inoue, H., Agishi, Y., Schuh, A. (2017). Climatotherapy in Japan: a pilot study. International Journal of Biometeorology, 61(12), 2141-2143. https://doi.org/10.1007/s00484-017-1418-x

Kántor, N., Unger, J. (2011). The most problematic variable in the course of human-biometeorological comfort assessment - the mean radiant temperature. Central European Journal of Geosciences, 3(1), 90-100. https://doi.org/10.2478/s13533-011-0010-x

Kazandjieva, J., Grozdev, I., Darlenski, R., Tsankov, N. (2008). Climatotherapy of psoriasis. Clinics in Dermatology, 26(5), 477-485. https://doi.org/10.1016/j.clindermatol.2008.05.001

Kenny, G.P., Flouris, A.D. (2014). 13 - The human thermoregulatory system and its response to thermal stress. In F. Wang, Ch., Gao (Eds.), Woodhead Publishing Series in Textiles (pp. 319-365). Woodhead Publishing. https://doi.org/10.1533/9781782420408.3.319

Kolendowicz, L., Półrolniczak, M., Szyga-Pluta, K., Bednorz, E. (2018). Human-biometeorological conditions in the southern Baltic coast based on the universal thermal climate index (UTCI). Theoretical and Applied Climatology, 134(1), 363-379. https://doi.org/10.1007/s00704-017-2279-2

Koo, J., Nakamura, M. (2017). Heliotherapy. In Clinical Cases in Phototherapy (pp. 77-80). Springer International Publishing. https://doi.org/10.1007/978-3-319-51599-1_10

Kozłowska-Szczęsna, T., Błażejczyk, K., Krawczyk, B., Limanówka, D. (2002). Bioklimat uzdrowisk polskich i możliwości jego wykorzystania w lecznictwie. Monografie, 3, Warsaw: IGiPZ PAN. http://rcin.org.pl/igipz/Content/2537/WA51_13510_r2004-t3_Monografie.pdf

Kozłowska-Szczęsna, T., Krawczyk, B., Błażejczyk, K. (2004). The main features of bioclimatic conditions at Polish health resorts. Geographia Polonica, 77(1), 45-61. http://rcin.org.pl/igipz/Content/92/GP_77_1.pdf\#page=42

Koźmiński, C., Michalska, B. (2019). Ocena bioklimatycznych warunków rekreacji i turystyki w strefie polskiego Wybrzeża Bałtyku na podstawie wskaźnika UTCl. Przegląd Geograficzny, 91(2), 113-126. https://doi.org/10.7163/PrzG.2019.2.7

Koźmiński, Cz., Michalska, B., Szczepanowska, E., Górnik, K. (2013). Zarys turystyki zdrowotnej i uzdrowiskowej. Wydawnictwo Naukowe Uniwersytetu Szczecińskiego.

Krawczyk, B. (2001). Ryzyko wystapienia stresu ciepła w wybranych uzdrowiskach polskich. Balneologia Polska, 43(1-2), 88-93.

Krzyżewska, A., Wereski, S., Dobek, M. (2020). Summer UTCl variability in Poland in the twenty-first century. International Journal of Biometeorology. https://doi.org/10.1007/s00484-020-01965-2

Kuchcik, M. (2017). Warunki termiczne w Polsce na przełomie XX i XXI wieku i ich wpływ na umieralność. Prace Geograficzne, 263, Warsaw: IGiPZ PAN.

http://rcin.org.pl/igipz/Content/66132/WA51_85081_r2017-nr263_Prace-Geogr.pdf 
Kuchcik, M., Błażejczyk, K., Szmyd, J., Milewski, P., Błażejczyk, A., Baranowski, J. (2013). Potencjał leczniczy klimatu Polski. Warsaw: Wydawnictwo Akademickie SEDNO. http://rcin.org.pl/igipz/Content/56052/WA51_74960_r2013_Potencjal-leczniczy.pdf

Lindner-Cendrowska, K., Błażejczyk, K. (2013). Clothing habits during tourism and leisure activities in urban areas. The case study of Warsaw (Poland). In J.D. Cotter, S.J.E. Lucas, T. Mündel (Eds.), Environmental Ergonomics XV, Proceedings of the 15th International Conference on Environmental Ergonomics (pp. 288-290).

Lindner-Cendrowska, K., Błażejczyk, K. (2018). Impact of selected personal factors on seasonal variability of recreationist weather perceptions and preferences in Warsaw (Poland). International Journal of Biometeorology, 62(1), 113-125. https://doi.org/10.1007/s00484-016-1220-1

Matzarakis, A., Mayer, H., Iziomon, M.G. (1999). Applications of a universal thermal index: physiological equivalent temperature. International Journal of Biometeorology, 43(2), 76-84. https://doi.org/10.1007/s004840050119

Mączyński, B. (1978). Lecznictwo klimatyczne. Wydawnictwo Lekarskie PZWL.

McMurray, R.G., Soares, J., Caspersen, C.J., McCurdy, T. (2014). Examining Variations of Resting Metabolic Rate of Adults: A Public Health Perspective. Medicine \& Science in Sports \& Exercise, 46(7), 1352-1358. https://doi.org/10.1249/MSS.0000000000000232

Ponikowska, I. (Ed.). (1995). Medycyna uzdrowiskowa w zarysie. Watext's.

Ponikowska, I. (Ed.). (2015). Encyklopedia Balneologii i Medycyny fizykalnej oraz Bioklimatologii, Balneochemii i geologii uzdrowiskowej (I). Konstancin-Zdrój: Wydawnictwo Aluna.

R Core Team. (2020). R: A Language and Environment for Statistical Computing. R: A Language and Environment for Statistical Computing. https://www.r-project.org/

Rintamäki, H., Rissanen, S. (2006). Heat Strain in Cold. Industrial Health, 44(3), 427-432. https://doi.org/10.2486/indhealth.44.427

Routh, H.B., Bhowmik, K.R., Parish, L.C., Witkowski, J.A. (1996). Basic tenets of mineral water: A glossary of concepts relating to balneology, mineral water, and the spa. Clinics in Dermatology, 14(6), 549-550. https://doi.org/10.1016/S0738-081X(96)00082-X

Rutty, M., Scott, D. (2015). Bioclimatic comfort and the thermal perceptions and preferences of beach tourists. International Journal of Biometeorology, 59(1), 37-45. https://doi.org/10.1007/s00484-014-0820-x

Schlader, Z.J., Stannard, S.R., Mündel, T. (2010). Human thermoregulatory behavior during rest and exercise - A prospective review. Physiology \& Behavior, 99(3), 269-275. https://doi.org/https://doi.org/10.1016/j.physbeh.2009.12.003

Schuh, A. (1993). Climatotherapy. Experientia, 49(11), 947-956. https://doi.org/10.1007/BF02125641

Staiger, H., Laschewski, G., Grätz, A. (2012). The perceived temperature - a versatile index for the assessment of the human thermal environment. Part A: scientific basics. International Journal of Biometeorology, 56(1), 165-176. https://doi.org/10.1007/s00484-011-0409-6

Stapleton, J.M., Larose, J., Simpson, C., Flouris, A.D., Sigal, R.J., Kenny, G.P. (2013). Do older adults experience greater thermal strain during heat waves? Applied Physiology, Nutrition and Metabolism, 39(3), 292-298. https://doi.org/10.1139/apnm-2013-0317

Vanos, J.K., Warland, J.S., Gillespie, T.J., Kenny, N.A. (2010). Review of the physiology of human thermal comfort while exercising in urban landscapes and implications for bioclimatic design. International Journal of Biometeorology, 54(4), 319-334. https://doi.org/10.1007/s00484-010-0301-9 